\title{
EFEKTIVITAS FORMULASI SEDIAAN LOTION DARI EKSTRAK ETANOL DAUN ALPUKAT (Persea americana MilI) SEBAGAI PELEMBAB KULIT
}

\author{
Hastrina Novasari ${ }^{1}$, Asti Pratiwi ${ }^{2}$, Nopri Mahmiara ${ }^{3}$ \\ Institut Kesehatan Medistra Lubuk Pakam, Jl. Sudirman No.38 Lubuk Pakam \\ Kab. Deli Serdang Prov. Sumatera Utara. \\ e-mail: novasarihastrina@gmail.com \\ DOI $10.35451 / \mathrm{jfm} . v 3 \mathrm{i} 2.571$
}

\begin{abstract}
Avocado plant can be formulated into a lotion because preparation based on previous research avocado leavescontain high antioxidant is represented with flavonoid compound. The purpose of this study is to know avocado leaves can be formulated into the preparation of lotion and to know the preparation of lotion from extract etanol avocado leavescan moisturaize the skin.

The research uses exsperimental method. Avocado leaves is exstrach by maceration process. Exanination of lotion preparation by this research is phytochemical screening test, $\mathrm{pH}$ test,irritation test and skin moisturaise test with concentration 3\% and 5\%. Extrach ethanol avocado leaves can be formulated into a skin moisturaizing lotion preparation with irritation test results showed no irritation on the skin, skin moisture examination result concentration $5 \%$ moist. The result showed that moisturaizing lotion preparation from avocado leaves ethanol extrach (Persea americana Mill) for skin moisture with different concentration can be formulated into skin moisturaizing lotion preparation.
\end{abstract}

Keywords: Avocado Leaf Extrach, Skin Moisture, Skin Moisturizing Lotion 


\section{Pendahuluan}

Alpukat merupakan tanaman yang berasal dari Amerika tengah, kemudian tanaman ini dengan cepat menyebar kenegara tropis dan sub-tropis seperti Indonesia. Tanaman ini tumbuh baik didataran rendah dan dataran tinggi yang memiliki curah hujan sekitar 1.500-3.000 $\mathrm{mm}$ per tahun. Hampir seluruhmasyarakat di Indonesia mengetahui dan meyukai buah alpukat karena kandungan gizi yang baik. Di Iindonesia peminatan buah alpukat sangat tinggi mencapai 290.810 ton tahun 2012 dan rata-rata 243.940 ton pada 10 tahun terakhir (Fauziah, dkk, 2016).

Daun alpukat diketahui memiliki kandungan aktivitas antioksidan yang tinggi. Senyawa bioaktif yang berperan adalah saponin, alkaloid, flavonoid, terfenoid, safrol, dan tannin. Senyawa antioksidan merupakan penyalur elektron, yaitu senyawa yang dapat menangkal dampak negatif oksidan. Antioksidan bermanfaat dalam mencegah penuaan dini. Penggunaan daun alpukat sebagai antioksidan perlu dikembangan menjadi suatu bentuk sediaan topikal pelindung kulit karena masih sangatjarang digunakan (Dina Maulana, 2016).

Antioksidan bekerja dengan cara mendonorkan satu elektronnya ke senyawa oksidan sehingga dapat terjadi penghambatan aktivitas senyawatersebut. Radikal bebas merupakan suatu atom, molekul, ataupun senyawa tunggal sehingga bersifat sangat reaktif dan tidak stabil. Elektron tunggal selalu berusaha mencari pasangannyaagar memudahkan interaksi dengan zat lain dalam tubuh seperti protein, lemak, dan DNA (Sayuti dan Yenrina, 2015).

Kosmetik perawatan kulit yang ada dipasaran tersedia dalam berbagai bentuk sediaan diantaranya adalah lotion. Dasar tipe lotion kulit adalah fase minyak 10$15 \%$, humektan 5-10\%, dan fase air 75$85 \%$. Minyak merupakan fase terdispersi sedangkan air merupakan fase pendispersi. Terpisahnya dua fase ini dapat dihindari dengan penambahan emulgator. Tipe motion M/A paling sering digunakan sebagai dermatologi topikal karena kualitas absorbsi yang sangat baik. Tipe M/A dibuat menjadi kosmetik yang mudah menyebar rata dan lebih mudah dibersihkan dengan air (Mardikasari, dkk, 2017).

Lotion termasuk sediaan yangpaling sering dipakai masyarakat Indonesia baik remaja maupun dewasa. Lotion mengandung bahan pelembut kulit (emolien) yang berefek sebagai antioksidan dan membantu terjadinya interaksi antara ekstrak tunggal dari alam dengan bahan tambahan seperti emulgator, pelembab, pewangi, dan pengawet. Lotion memiliki tingkat kestabilan yang sangat baik dibandingkan menggunakan ekstrak secara langsung. Kulit memiliki lapisan pelindung tubuh yang baik dari paparan polusi lingkungan. Kulit wajah lebih sering terpapar sinar ultraviolet (UV) dibandingkan kulit bagian yang lain, akibatnya sering menimbulkan masalah kulit. Keriput, penuaan dini, pori membesar, dan jerawat adalah contoh masalah kulit yang sering terjadi (Grace, 2015).

Pada penelitian sebelumnya (Dina, 2016) Formula sediaan krim antioksidan ekstrak etanolik daun alpukat yang konstratnya dapat diformulasikan dalam sediaan krim sebagai antioksidan dan baik untuk melembabkan kulit karena nilai $\mathrm{pH}$ krim yang mengandung ekstrak daun alpukat berada dalam kisaran pHyang memenuhi strandar SNI yang berkisar antara 4,5-8. Adapun hasil dari sediaan krim dari ekstrak daun alpukat menunjukkan $\mathrm{pH} 6$.

Berdasarkan latar belakang, peneliti tertarik untuk meneliti formulasi sediaan lotion dari ekstrak etanol daun alpukat sebagai pelembab kulit.

\section{Metode}

Metode Eksperimen ini merupakan jenis quast eksperimental dengan pre 
test dan post test desain penelitian. Dalam penelitian ini observasi dan pengukuran dilakukan sebelum dan sesudah perlakuan untuk melihat manakah sediaan lotion pelembab kulit dan ekstrak daun alpukat pada konsentrasi mana yang lebih baik diaantara sediaan lotion pelembab kulit dari konsentrasi 3\% dan 5\% sediaan lotion pelembab kulit dari sediaan lotion.

Pembuatan Sediaan Lotion

\begin{tabular}{lcc}
\hline Komposisi & \multicolumn{2}{c}{ Formulasi } \\
\cline { 2 - 3 } Asam Stearat & $\mathrm{A}$ & $\mathrm{B}$ \\
Setil Alkohol & 0,5 & 12 \\
Trietanolamin & 1 & 0,5 \\
Ekstrak daun & 3 & 5 \\
alpukat & & \\
Nipagin & 0,1 & 0,1 \\
Nipasol & 0,2 & 0,2 \\
Air suling & 86,06 & 83,065 \\
& 5 & \\
Olium rosae & 0,135 & 0,135 \\
\hline
\end{tabular}

Ket : Formula $\mathrm{A}$ : Konsentrasi serbuk daun alpukat $3 \%$

Formula B : Konsentrasi serbuk daun alpukat $5 \%$

\section{Prosedur kerja :}

Lumpang porselin diisi air panas \pm $90^{\circ} \mathrm{C}$ lalu didiamkan, tunggu sampai dinding luar lumpang terasa panas. Selanjutnya air panas dibuang dan lumpang dikeringkan. Bahan-bahan untuk membuat dasar lotion ditimbang. Asam stearat dan setil alkohol dipanaskandiatas penangas air dengan suhu $\pm 70^{\circ} \mathrm{C}$ (massa I). Nipagin nipasol dan trietanolamin dilarutkan menggunakan aquadest yang telah dipanaskan dengan suhu $\pm 70^{\circ} \mathrm{C}$ (massa II). Massa I dan massa II dimasukkan kedalam lumpang porselin yang panas lalu digerus sehinggadiperoleh massa lotion yang cair. Estrak daun alpukat dihaluskan dan ditimbang. Lalu ditambahkan dasar lotion yang telah ditimbang dan dicampur sampai homogen. Ditambahkan parfum sebanyak
3 tetes, diaduk, kemudian dimasukkan kedalam wadah pot plastik.

\section{Pemeriksaan Terhadap Sediaan}

\section{Pemeriksaan Homogenitas}

Pemeriksaan Terhadap Sediaan meliputi pemeriksaan homogenitasdengan cara sediaan di oleskan di atas sekeping kaca dengan syarat sediaan tersebut tidak terlihat adanya butiran butiran kasar (Ditjen POM, 1995).

\section{Pemeriksaan Organoleptis}

pemeriksaan organoleptis menggunakan objek glas dengan cara: dioleskan sejumlah tertentu pada objek glas lalu diamati bentuk, warna, dan bau sediaan lotion tersebut (Ditjen POM, 1995).

\section{Pengukuran pH Sediaan}

Pengukuran $\mathrm{pH}$ Sediaan PenetuanPh sediaan menggunakan $\mathrm{PH}$ meter. Alat dikalibrasi menggunakan larutan dapar standar netral $(7,01)$ dan larutan dapar $\mathrm{pH}$ asam $(4,01)$ sampai nilai $\mathrm{PH}$ muncul pada alat. Kemudiaan elektroda dicuci menggunakan air suling, dan dikeringkan dengan tissue, sampel dengan konsentrasi $1 \%$ ditimbang $1 \mathrm{~g}$, dilarutkan dalam $100 \mathrm{ml}$ air suling. Elektroda dicelupkan dan dibiarkan angka $\mathrm{pH}$ sampai konstan. Angka yang muncul merupakan $\mathrm{pH}$ dari sediaan (Karim, dkk, 2013).

\section{Sampel Penelitian}

Sampel penelitian yaitusukarelawan, dijadikan untuk uji homogentias, uji $\mathrm{pH}$, uji stabilitas sediaandan uji kelembaban kulit dengan jumlah

10 orang. Teknik pengambilan sampel berupa non-probility sampling dengan pendekatan teknik purposive sampling. Sampel pada penelitian ini diambil dari sebagian populasi yang telah memenuhi kriteria inklusi. Berikut kriterianya :

$$
>\text { Kriteria inklusi (kriteria }
$$

a. Wanita dan pria tidak ada riwayat alergi 

b. Lulus uji kelembaban $(40 \%-60 \%)$
c. Bersedia menjadi responden.
d. Berdasarkan Usia (20-30 tahun).

\section{Metode Pengumpulan Data}

Metode Pengumpulan Data

Penelitian ini menggunakan metode observasi. Dilakukan sebelum perlakuan (pre-test) dan setelah perlakuan (post test).

\section{Hasil}

\section{Hasil Ekstrak Daun Alpukat}

Hasil yang didapat dari proses ekstraksi dari 2,5 kg daun alpukat dengan menggunakan pelarut etanol $96 \%$ yang dipekatkan dengan rotaryevaporatorpada suhu $\pm 80^{\circ} \mathrm{C}$ yaitu berupa ekstrak $300 \mathrm{gr}$. Hasil Uji Skrining Fitokimia Daun Alpukat

Tabel 4.1 Hasil uji identifikasi senyawa Flavonoid estrak etanolik Daun Alpukat dengan peraksi warna

\begin{tabular}{cccc}
\hline $\begin{array}{c}\text { Golo } \\
\text { ngan }\end{array}$ & $\begin{array}{c}\text { Senyawa } \\
\text { Pereaksi }\end{array}$ & $\begin{array}{c}\text { Penga } \\
\text { matan }\end{array}$ & Hasil \\
\cline { 1 - 2 } Flavo & $10 \mathrm{mg}$ & Merah & $(+)$ \\
noid & $\begin{array}{c}\text { Serbuk } \\
\text { direndam }\end{array}$ & & \\
& air panas, \\
& filtrat + \\
& $100 \mathrm{mg}$ \\
& & \\
& serbuk Mg \\
& $+1 \mathrm{ml}$ \\
& HCL pekat \\
& $+2 \mathrm{ml}$ \\
& amil \\
& alkohol \\
&
\end{tabular}

\section{Penentuan Fisik Mutu Lotion}

\section{Hasil Uji Homogenitas}

Hasil pengamatan homogenitas menunjukkan bahwa semua formula sediaan lotion estrak etanol daun alpukat memiliki susunan yang homogen, tidak terasa adanya butir-butir kasar pada plat kaca saat diujikan. Sehingga dapat dikatakan sediaan lotion stabil dalam hal homogenitasnya.

\section{Hasil Uji Organoleptis}

Hasil uji organoleptis yang dilakukan terhadap sediaan pada formula I dan II dapat dinyatakan lulus uji organoleptis karena tidak ada perubahan warna, bentuk dan bau terhadap sediaan tersebut selama penyimpanan selama 1 minggu.

\section{Hasil Pengukuran pH Sediaan}

Hasil pengukuran $\mathrm{pH}$ sediaan lotion menunjukkan bahwa semua formula sediaan Lotion tingkat keasaman 6 . Nilai $\mathrm{pH}$ kulit normal berkisaran antara 4,5-6,0 (Akhtar dkk, 2011). Sedangkan menurut SNI nilai $\mathrm{pH}$ sediaan pelembab kulit yang baik berkisaran antara 4,5-8. Nilai $\mathrm{pH}$ lotion yang mengandung ekstrak daun alpukat masih berada dalam kisaran $\mathrm{pH}$ yang memenuhi standar SNI. hasil pengukuran ph selama 1 minggu menunjukkan bahwa kedua formulasitidak mengalami perubahan $\mathrm{pH}$.

\section{Hasil Uji Iritasi Kulit}

Tabel 4.2 Data Uji Iritasi Terhadap Responden

\begin{tabular}{|c|c|c|c|c|c|c|c|c|c|c|}
\hline \multirow{2}{*}{$\begin{array}{l}\mathbf{N} \\
\mathbf{O}\end{array}$} & \multirow{2}{*}{$\begin{array}{l}\text { Tand } \\
\text { a } \\
\text { Irita } \\
\text { si }\end{array}$} & \multicolumn{9}{|c|}{ Responden } \\
\hline & & $\begin{array}{ll}\text { I } & \text { I } \\
& \text { I }\end{array}$ & $\begin{array}{l}\mathrm{I} \\
\mathrm{I} \\
\mathrm{I}\end{array}$ & $\begin{array}{l}\mathrm{I} \\
\mathrm{V}\end{array}$ & $\mathrm{V}$ & $\begin{array}{l}\text { V } \\
\text { I }\end{array}$ & V & $\begin{array}{l}\mathrm{V} \\
\mathrm{II} \\
\mathrm{I}\end{array}$ & $\begin{array}{l}\mathrm{I} \\
\mathrm{X}\end{array}$ & $\bar{x}$ \\
\hline & $\begin{array}{l}\text { Keme } \\
\text { rahan }\end{array}$ & $-\quad-$ & - & - & - & - & - & - & - & - \\
\hline & $\begin{array}{l}\text { Gatal } \\
\text { Panas }\end{array}$ & $\begin{array}{l}- \\
=-\end{array}$ & $\begin{array}{l}- \\
-\end{array}$ & $\begin{array}{l}- \\
=\end{array}$ & $\begin{array}{l}- \\
\overline{-}\end{array}$ & - & - & - & 政 & $\begin{array}{l}- \\
-\end{array}$ \\
\hline
\end{tabular}

Hasil Uji Kelembapan Sebelum dan Sesudah Pengolesan

Tabel 4.3 Data pengukuran persen kelembapan kulit sebelum pengolesan sediaan.

\begin{tabular}{|c|c|c|}
\hline No & Responden & $\begin{array}{c}\text { Data } \\
\text { pengukuran } \\
\text { kelembapan } \\
\text { kulit sebelum } \\
\text { dioleskan }\end{array}$ \\
\hline
\end{tabular}




\begin{tabular}{ccc}
\hline 1 & I & $32,2 \%$ \\
2 & II & $33,3 \%$ \\
3 & III & $30,3 \%$ \\
4 & IV & $32,2 \%$ \\
5 & V & $30,4 \%$ \\
6 & VI & $31,2 \%$ \\
7 & VII & $33,6 \%$ \\
8 & VIII & $34,2 \%$ \\
9 & IX & $32,6 \%$ \\
10 & X & $31,9 \%$ \\
& Rata-rata & $33,56 \%$ \\
\hline
\end{tabular}

Tabel 4.4 Data pengukuran persen kelembapan kulit setelah pengolesan Sediaan Lotion

\section{No Responden}

\section{Data pengukuran} persen

kelembapan kulit setelah pengolesan sediaan lotion

\section{3\%}

$47,2 \%$

\section{$\mathbf{5 \%}$}

$\begin{array}{cccc}1 & \text { I } & 47,2 \% & 53,1 \% \\ 2 & \text { II } & 46,2 \% & 52,4 \% \\ 3 & \text { III } & 48,1 \% & 52,1 \% \\ 4 & \text { IV } & 47,5 \% & 52,4 \% \\ 5 & \text { V } & 46,3 \% & 54,2 \% \\ 6 & \text { VI } & 46,2 \% & 53,2 \% \\ 7 & \text { VII } & 46,3 \% & 53,6 \% \\ 8 & \text { VIII } & 47,3 \% & 50,4 \% \\ 9 & \text { IX } & 48,2 \% & 51,2 \% \\ 10 & \text { X } & 48,5 \% & 49,5 \% \\ & \text { Rata-rata } & 47,18 \% & 52,21 \%\end{array}$

Tabel 4.5 Rata-rata persen (\%) kelembapan kulit setelah pengolesan sediaan.

\begin{tabular}{cccc}
\hline No & $\begin{array}{c}\text { Form } \\
\text { ula }\end{array}$ & $\begin{array}{c}\text { Rata-rata } \\
\text { kelembap } \\
\text { an setelah } \\
\text { pengolesa } \\
\text { n lotion }\end{array}$ & $\begin{array}{c}\text { Skala } \\
\text { kelemba } \\
\text { pan skin } \\
\text { analyzer }\end{array}$ \\
\hline 1 & SEDA & $47,18 \%$ & Lembab \\
& $3 \%$ & & Lembab \\
2 & SEDA & $52,21 \%$ & \\
\hline
\end{tabular}

\section{Pembahasan}

Berdasarkan hasil penelitian yang telah dilakukan dapat dilihat bahwa dengan berbagai pengujian yang dilakukan yaitu penentuan fisik lotion, seperti uji homogenitas menunjukan hasil bahwa semua formula sediaan lotion estrak etanol daun alpukat memiliki susunan yang homogen, dan hasil uji organoleptis menunjukan Hasil dapat dinyatakan lulus uji organoleptis karena tidak ada perubahan warna, bentuk dan bau terhadap sediaan tersebut selama penyimpanan selama 1 minggu. Dan adapaun pada pengukuran $\mathrm{pH}$ selama 1 minggu menunjukkan bahwa kedua formulasi tidak mengalami perubahan pH.Dan pada pengujian iritasi kulit tidak terlihat adanya efek samping berupa kemerahan, gatal, panas, dan kering pada kulit yang ditimbulkan oleh sediaan. Maka sediaan lotion tersebut telah memenuhi syarat.

\section{Kesimpulan}

Berdasarkan pengujian kelembaban dapat dilihat bahwa semakin tinggi konsentrasi ekstrak daun alpukat ditambahkan pada sediaan lotion, maka semakin tinggi kemampuan untuk melembabkan kulit, hal ini terlihat pada konsentrasi $5 \%$ lebih banyak mengandung ekstrak daun alpukat dimana ekstrak daun alpukat berfungsi untuk melembabkan kulit. Berdasarkan hasil uji kelembapan diketahui bahwa formulasi ekstrak daun alpukat dengan konsentrasi 3\% dan 5\% memberi efek melembabkan kulit.

Menurut referensi alat skin analyzer, kriteria kelembaban kulit adalah jika lebih kecil dari 40\% kurang lembab, 40-60\% lembab, dan lebih besar dari $60 \%$ sangat lembab, berarti semua formula dapat melembabkan kulit dengankatagori lembab.

\section{Daftar Pustaka}


Dina Maulana, dkk. 2016. Formulasi Sediaan Krim Antioksidan Ekstrak Etanolik Daun Alpukat. Purwokerto: Universitas Jendral Sudirman.

Fuziah, Nidiya Ayu, dkk. 2016. Ekstarksi dan Uji Stabilitas Zat Warna Dari Kulit Buah Alpukat ( Persea Americana Mill). Jurnal atomic. Hal 23-27.

Grace, F.X., C, dkk. 2016. Preparationand Evaluation of Herbal Peel Off Face Mask. American Journal of Phamtech Research. (5): 33-336.

Mardikasari dkk. 2017. Formulasi Dan Uji Stabilitas Lotion Ekstrak Etanol Daun Jambu Biji Sebagai Antioksidan. Jurnal Farmasi, Sains, dan Kesehatan. 3(2): 28-32.

Sayuti, K. Rina Yenrina. 2015, Antioksidan Alami dan sintetik. padang: Andalas University Press.

Ditjen POM . 1995. Farmakope Indonesia. Edisi Kelima. Jakarta: Depkes RI. 